\title{
Možnosti extrapolace digitálního modelu terénu z rastru DMR 5G
}

\section{MARTIN CALETKA}

Klíčová slova: DMR 5G - digitální model terénu - extrapolace - GIS - tvar koryta

\section{SOUHRN}

Nad územím celé České republiky bylo provedeno letecké laserové snímkování (LiDAR), díky němuž je možné vytvářet rastry digitálního modelu terénu. Tyto podklady mají široké uplatnění v různých odvětvích. Z hlediska potřeb hydrologie je však nedostatkem použité technologie nepřesné, resp. neúplné, vykreslení tvaru koryt, nebot' laserové paprsky blízkého infračerveného záření jsou absorbovány vodou. Z toho důvodu je potřebné data korigovat nahrazením jejich části např́klad výstupy z jiných měření, např. teodolitem či sonarem. Existují však postupy, pomocí kterých je možné geometrii koryt extrapolovat prímo z původních rastrů, a to na základě sklonů břehů v rámci prríčných profilů. $V$ rámci této práce se vychází z postupu linear and double-linear estimation method podle Mersela a kol. [1].

Předložená práce predstavuje úvodní krok směrem k využití podobných extrapolačních postupư. Celkem 82 profilů bylo geodeticky zaměřeno a následně byly extrahovány př́íné profily z rastru DMR 5G, na nichž byla prováděna extrapolace. Na dosavadním souboru príčných profilů se ukázalo, že extrapolační metoda vede k mírnému nadhodnocování minimální úrovně dna koryt oproti skutečně zaměřeným hodnotám. Z toho důvodu bylo také zjištóováno, nakolik je potřeba úhly sklonů břehů zvýšit, aby bylo dosaženo dobré shody se skutečně naměřenými daty. Podstatné však je, že srovnávání bylo prozatím prováděno čistě na základě shody nejnižší úrovně dna v príčném profilu, nikoli z hlediska vlivu na výsledky hydrodynamického modelování.

\section{ÚVOD}

Modelování v hydrologii je kromě dobré znalosti a simulace fyzikálních procesů ovlivňováno významně i nepřesnostmi vstupních dat. Nejistotami v hydrologickém modelování se zabývala řada prací [2-4]. Zdroje nepřesností mohou plynout napríklad z hodnot průtoků odvozených prostřednictvím hydrologického modelu, v němž již vstupní data (např. srážkové úhrny či vlhkost půdy) vykazují určité nepřesnosti [5]. Pokud je průtok odvozován z měření vodních stavů, je přesnost ovlivněna kvalitou vztahu vodní stav/průtok $[2,6]$. Problematickým faktorem při modelování povodňových rozlivů je také nastavení hodnoty součinitele drsnosti [7-9] a geometrický popis koryta a řiční nivy (např. [10-16]).

Problematice prípravy kvalitního digitálního modelu terénu (DMT) je v hydrologii věnováno značné úsilí. Zpresňování DMT je možné provádět pomocí různých přístupů, především interpolací geodeticky zaměřených prríčných profilů koryta či interpolací samostatně zaměěených bodů batygrafie a jejich integrací s okolním terénem [2]. Značného pokroku v rámci modelování obecně bylo dosaženo zavedením technologie leteckého laserového snímkování terénu ( $z$ angl. Light Detection and Ranging - akronym LiDAR). Jedná se o technologii,

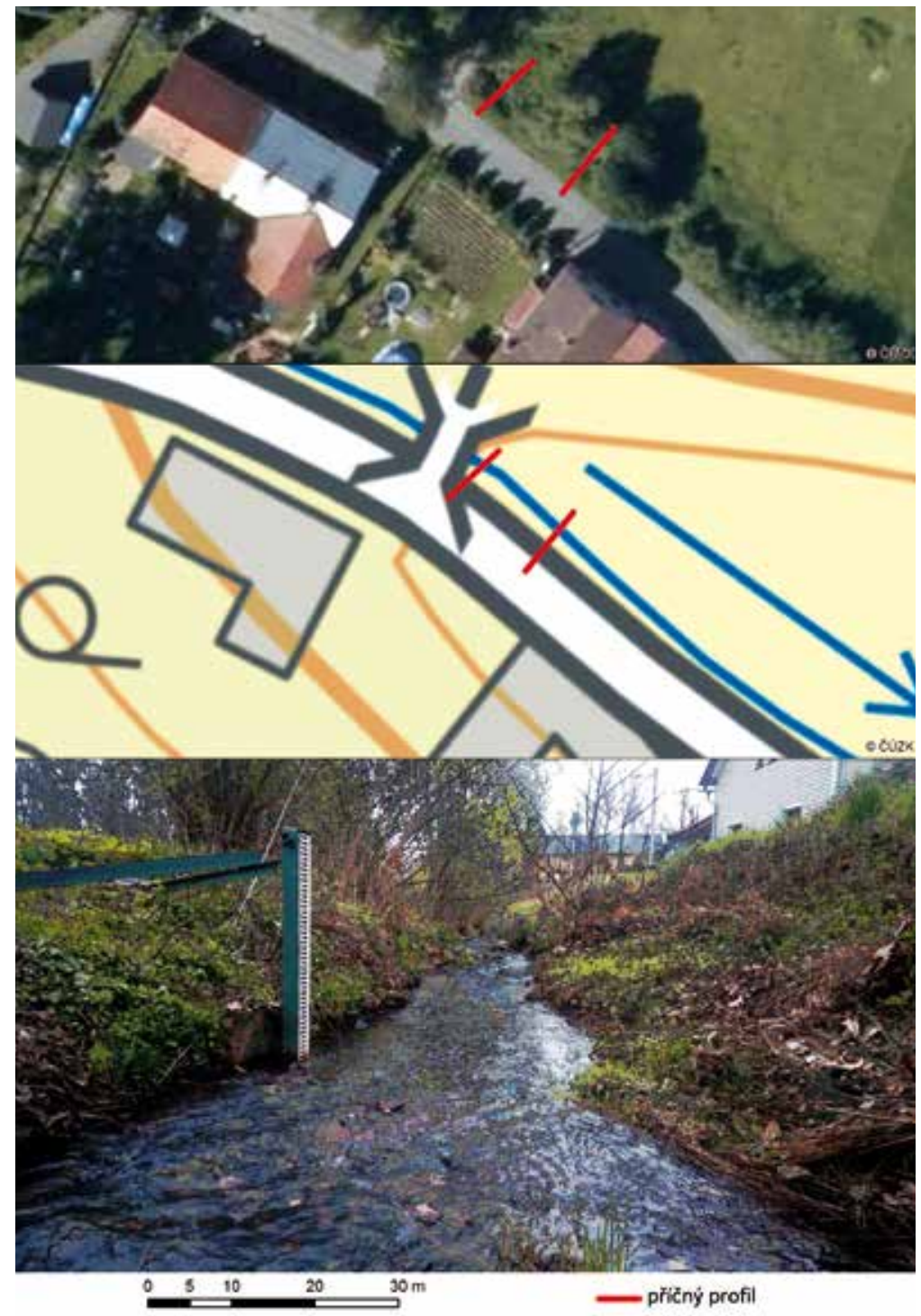

Obr. 1. Ukázka měřeného příčného profilu na úseku Husího potoka ve Vlkovicích u Fulneku

Fig. 1. An example of a measured cross-section profile on the Husí brook in VIkovice near Fulnek 


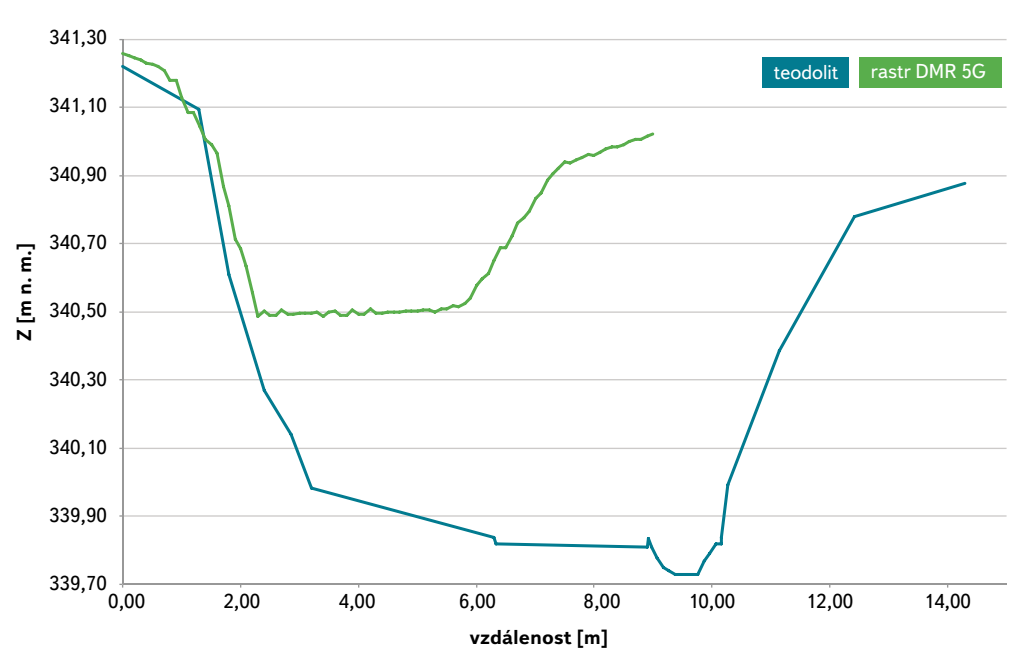

Obr. 2. Srovnání příčného profilu koryta Husího potoka ve Vlkovicích zaměřeného teodolitem a extrahovaného z DMT DMR $5 G$

Fig. 2. Comparison of cross-section profiles on the Husí brook in Vlkovice measured by theodolite and extracted from the DMT DMR 5G

která umožňuje měřit zejména nadmořskou výšku povrchu (tzv. topo LiDAR system) [17, 18]. Měřená data jsou ukládána ve formě mračna bodů [19]. I přes značné zlepšení může být přesnost měřených dat omezena. Laserový paprsek nemusí vždy proniknout až k zemskému povrchu v prípadě husté vegetace či zástavby. Navíc může docházet k pohlcování laserového paprsku vodou [20]. Absence topografie vodou vyplněných částí vodních útvarů přitom představuje významný problém z hlediska modelování hydrauliky proudění [11, 13, 14]. Z toho důvodu byl kromě technologií, jako je sonar [21], digitální fotogrammetrie [22] či satelitní měření [23], vyvinut typ LiDARu umožňující i měření batygrafie (bathymetric LiDAR system). Na rozdíl od tradičního LiDARu, využívajícího blízké infračervené záření, použivá vInové délky zelené části spektra, které pronikají vodou [24].

Pro eliminování chyb spojených s využíváním konvenčních měření LiDARem (výstupem takového měření je i sada DMR 4G a DMR 5G) vznikla řada extrapolačních metod pro určení topografie části koryt, resp. přínných profilů koryt, vyplněných vodou. Základní a nejjednodušší metodou je tzv. linear a double-linear method [1, 25], spočívající v extrapolaci sklonu břehů směrem do koryta toku. Hlavním cílem tohoto článku je: 1. provést prvotní srovnání výstupů obou zmíněných extrapolačních metod s geodeticky zaměřenými příčnými profily

Tabulka 1. Charakteristiky přesnosti DMR 5 G na rưzném povrchu a pưdním krytu (převzato z Technické zprávy k Digitálnímu modelu 5. generace, ČÚZK, 2016)

Table 1. Accuracy characteristics of the of the DMR 5 G dataset for various types of surfaces (according to the Technical report of the digital model of relief $5^{\text {th }}$ generation)

\section{Kategorie povrchu a půdního krytu Úplná střední Maximální

chyba $[\mathrm{m}] \quad$ chyba $[\mathrm{m}]$

\begin{tabular}{lll}
\hline terénní hrany u komunikací & 0,18 & 0,66 \\
\hline zpevněné plochy & 0,13 & 0,37 \\
\hline orná půda & 0,14 & 0,56 \\
\hline louky a pastviny & 0,21 & 0,42 \\
\hline křoviny, stromořadí a lesy & 0,13 & 0,46 \\
\hline průměrná hodnota & 0,14 & 0,49
\end{tabular}

\section{EXTRAPOLACE KORYTA}

\section{Metody lineárního odhadu}

Nejjednoduššími způsoby odstranění zmíněných nedostatků jsou metody lineárního a dvojitého lineárního odhadu (linear and double-linear estimate method) [1]. Tyto metody jsou založeny na lineární extrapolaci linie terénu na obou 
stranách příčného profilu. Nejnižší bod koryta je dán průsečíkem obou extrapolovaných linií (obr. 3). Je zřejmé, že takto extrapolovaná hloubka je závislá na šîrce koryta a na úhlech sklonu $a$, $\beta$ obou břehů. Velikost úhlů $\alpha, \beta$ je vypočítána na základě vymezení břehů (levý břeh - body $A, B$; pravý břeh - body $C, D$ ). $\checkmark$ rámci studie bylo využito obou výše uvedených metod. Při metodě lineárního odhadu jsou velikosti úhlů $a, \beta$ zachovány a nejnižším bodem přičného profilu je bod E. Metoda dvojitého lineárního odhadu spočívá ve snížení úhlů $a, \beta$ na polovinu původní velikosti. Nejnižší bod je označen É. Průsečík vodorovné prímky se směrovým vektorem $\vec{h}$, procházející bodem $B$, s prímkou $p$ je bod F.

\section{Výpočet průsečíků E, E‘ se skládá z několika kroků:}

\section{PŘEVOD SOUŘADNIC BODŮ \\ Z KARTOGRAFICKÝCH NA RELATIVNI}

Souřadnice systému S-JTSK Křovák East North byly nahrazeny vzdálenostmi daného bodu od počátku příčného profilu.

\section{SESTAVENÍ OBECNÝCH ROVNIC PŘÍMEK OBOU BŘEHŮ}

Ze souřadnic bodů $A, B, C, D$ byly odvozeny vektory $\vec{u}$ a $\vec{v}$, což jsou směrové vektory prímek $l, p$.

$$
\begin{aligned}
& \vec{u}=\left(u_{1} ; u_{2}\right)=\left(A_{1}-B_{1} ; A_{2}-B_{2}\right) \\
& \vec{v}=\left(v_{1} ; v_{2}\right)=\left(D_{1}-C_{1} ; D_{2}-C_{2}\right)
\end{aligned}
$$

Obecné rovnice prímek I, p mají tvar:

$$
\begin{aligned}
& \text { I: } u_{2} x+\left(-u_{1}\right) y+c_{1}=0 \\
& \text { p: } v_{2} x+\left(-v_{1}\right) y+c_{p}=0
\end{aligned}
$$

\section{VÝPOČET PRŮSEČÍKU PŘíMEK OBOU BŘEHŮ}

Řešením soustavy rovnic (3) a (4) jsou souřadnice bodu $E\left[X_{E} ; Y_{E}\right]$. Souřadnice $Y_{E}$ určuje nadmořskou výšku průsečíku při použití metody lineárního odhadu.

\section{VÝPOČET ÚHLŮ SKLONŮ OBOU BŘEHŮ}

Zjištění úhlů $\alpha$, $\beta$ vychází ze vztahu pro kosinus úhlu dvou nenulových vektorů. Při znalosti směrových vektorů $\vec{u}$ a $\vec{v}$ prrímek $I, p$ postačí zvolit libovolný vektor $\vec{h}$ v horizontálním směru (např. $\vec{h}=(1 ; 0))$. Pak pro úhel a platí, že:

$$
\cos a=\frac{\vec{h} \cdot \vec{u}}{|\vec{h}| \cdot|\vec{u}|}=\frac{h_{1} u_{1}+h_{2} u_{2}}{\sqrt{h_{1}^{2}+h_{2}^{2}} \sqrt{u_{1}^{2}+u_{2}^{2}}}=\frac{u_{1}}{\sqrt{u_{1}^{2}+u_{2}^{2}}}
$$

a pro úhel $\beta$ :

$$
\cos \beta=\frac{\vec{h} \cdot \vec{v}}{|\vec{h}| \cdot|\vec{v}|}=\frac{h_{1} v_{1}+h_{2} v_{2}}{\sqrt{h_{1}^{2}+h_{2}^{2}} \sqrt{v_{1}^{2}+v_{2}^{2}}}=\frac{v_{1}}{\sqrt{v_{1}^{2}+v_{2}^{2}}}
$$

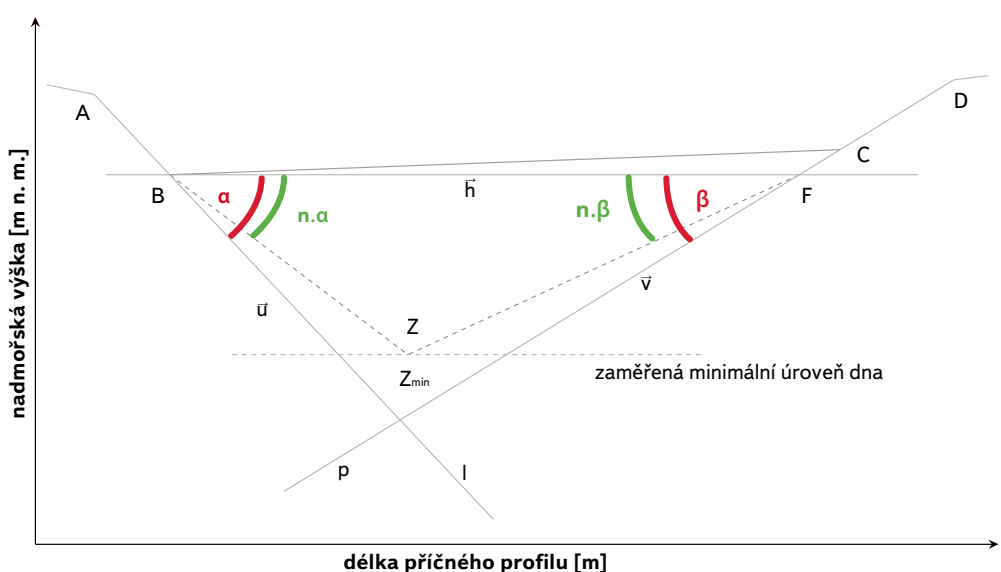

Obr. 4. Schématické znázornění metody n-násobkủ úhlů $\alpha, \beta$

Fig. 4. Schematic representation of the method of multiplier $n$

\section{VÝPOČET PRŮSEČÍKU PŘI POLOVIČNÍCH ÚHLECH}

Bod $E^{\prime}\left[E_{1}^{\prime} ; E_{2}^{\prime}\right]$ je průsečíkem prímek, které svírají s vektorem $\vec{h}$ úhly $a / 2, \beta / 2$. Při výpočtu souřadnic bodu je možné vycházet ze směrnicových rovnic přímek la p, které mají tvar:

$$
\begin{aligned}
& \text { l: } y=k_{1} x+q_{1} \\
& \text { p: } y=k_{p} x+q_{p}
\end{aligned}
$$

Kde čísla $k_{1}, k_{p}$ jsou směrnice prrímek $l, p$. Obecně platí, že směrnice $k$ dané prímky je rovna tangentě úhlu, který tato prímka svírá s kladnou poloosou $x$. Z toho plyne, že ze vztahů (7), (8) je možné sestavit rovnici:

$$
\operatorname{tg}(\alpha / 2) x+q_{1}=\operatorname{tg}(\beta / 2) x+q_{p}
$$

z níž je možné vypočítat výsledné souřadnice. Pro uvedený vztah však musí být současně splněny tyto podmínky, které jsou zrejemé z obr. 3:

$$
\begin{aligned}
& \text { pravá strana rovnice: } \operatorname{tg}(\alpha / 2) x+q_{l}=\operatorname{tg}(\beta / 2) x+q_{p} \\
& \text { levá strana rovnice: } \beta<\frac{\pi}{2} \wedge \beta>0
\end{aligned}
$$

\section{VÝPOČET ODCHYLEK OD ZAMĚŘENÉ NEJNIŽŠÍ ÚROVNĚ DNA} Pro obě extrapolační metody jsou nakonec vypočítány odchylky úrovně průsečíků prímek obou břehů od $Z_{\text {min }}$.

\section{METODA N-NÁSOBKU ÚHLŮ}

Metoda n-násobku úhlů je založena na hledání čísla $n$ takového, aby jeho součin s úhly $a, \beta$ určoval optimální úhly směrových vektorů přímek vưči $\vec{h}$. Průsečíkem těchto prímek $I, p$ by měl být bod $Z\left[Z_{1} ; Z_{2}\right.$, jehož souřadnice $Z_{2}$ se bude svou hodnotou bližit $Z_{\min }$ príslušného príčného profilu (obr. 4).

Při odvození vztahu pro výpočet číla $n$ je nutné vycházet ze směrnicových rovnic prímek I, p (7), (8). Čísla $k_{1}, k_{p}$ jsou směrnice prímek I, p. Obecně platí, že směrnice $k$ prímky je rovna tangentě úhlu, který svírá prímka s kladnou poloosou $x$. Z toho plyne, že ze vztahů (7) a (8) je možné sestavit rovnici: 

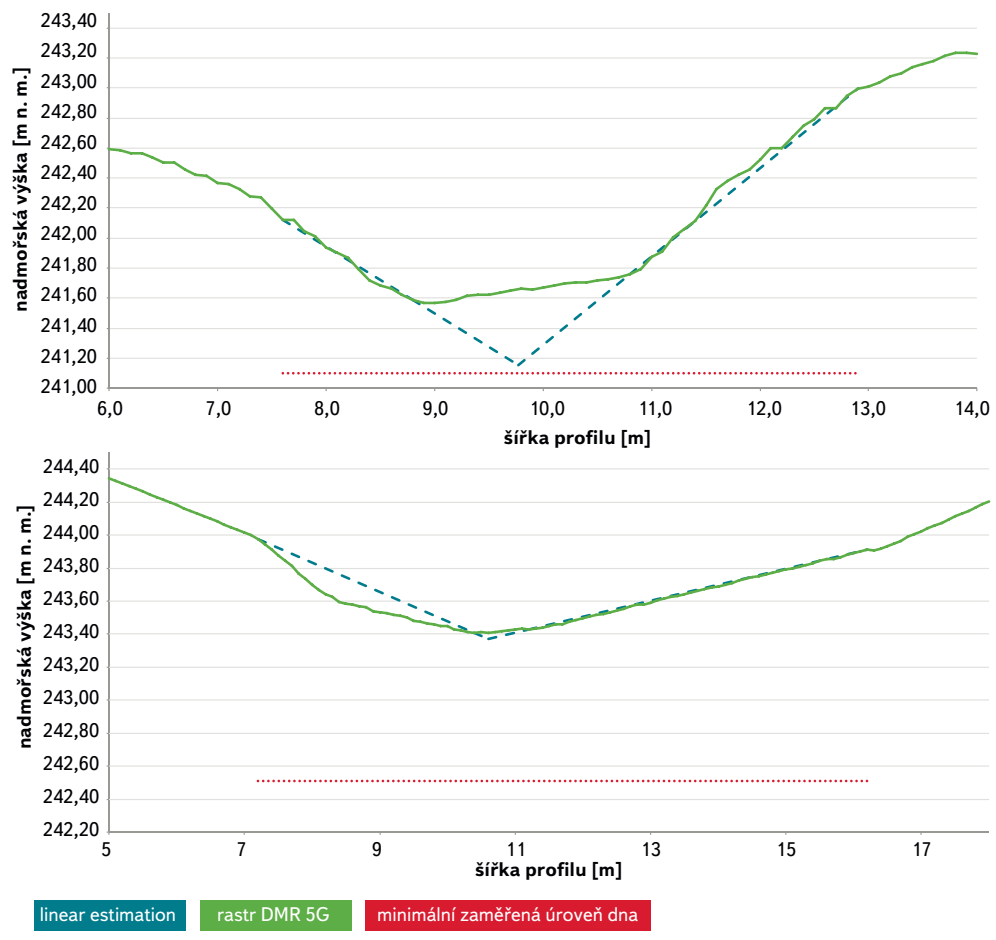

Obr. 5. Příklad príčného profilu s dobrou shodou (nahoře), neshodou minimální úrovně koryta extrapolovaného pomocí metody linear estimation (dole) [1]

Fig. 5. An example of a cross-section showin good match (above), discrepancy of the minimal level of channel bottom extrapolated by the linear estimation method (down) [1]

$$
\operatorname{tg}(n a) x+q_{1}=\operatorname{tg}(n \beta) x+q_{p}
$$

I zde musí současně platit podmínky:

$$
\begin{aligned}
& \text { pravá strana rovnice: } \pi-n a<\pi \wedge \pi-n a>\frac{\pi}{2} \\
& \text { levá strana rovnice: } n \beta<\frac{\pi}{2} \wedge n \beta>0
\end{aligned}
$$

Je-li známo, že otáčející se prímka / prochází bodem B a přímka p bodem C, umožňuje vztah (12) pro každý přičný profil najít optimální hodnotu číla $n$, a tím približení $k Z_{\min }$ daného příčného profilu.

Uvedený problém je možné řešit více způsoby. $V$ rámci této studie bylo využito programovacího jazyka Python. Základem sestaveného kódu je rovnice (9),

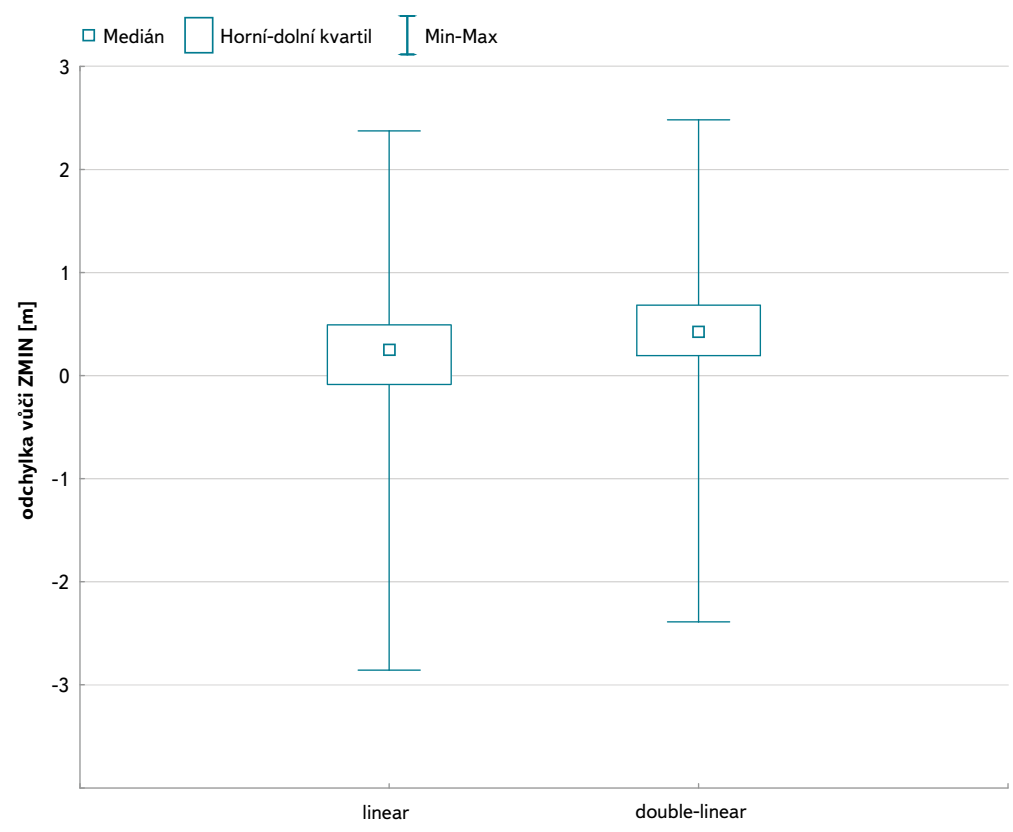

Obr. 6. Krabicový graf odchylek nejnižšího bodu extrapolovaného dna vưči $Z_{\min }$ zaměřené geodeticky

Fig. 6. Boxplot of the deviations of the lowest level in the extrapolated cross sections using the linear and double-linear estimation method [1] from the in situ geodetic measurements

do níz vstupují násobky pưvodních úhlů $a, \beta$. Obecně je tedy výpočet založen na zvyšování n od minima, plynoucího z podmínek (13) a (14), o velmi malý krok (napr. $10^{-5}$ ). Přitom je nutné zajistit opakované přepočítávání hodnot na, $n \beta$, $q_{1}, q_{p}$ a souřadnice $Z_{2^{\prime}}$ která určuje nadmořskou výšku průsečíku. $V$ okamžiku, kdy je poprvé zaznamenána hodnota $Z_{2}$ nižší než $Z_{\text {min, }}$ výpočet se zastaví a hodnota $n$ se sniží o hodnotu jednoho kroku, pro který je rovněž zjištěna hodnota $Z_{2}$. Nakonec je vybrána ta hodnota $n$, při níz je absolutní hodnota rozdílu vůči $Z_{\text {min }}$ menší.

\section{VÝSLEDKY}

Analýza zpracovaných prríčných profilů ukázala, že při využití lineární extrapolační metody podle Mersela a kol. [1] je možné dosáhnout poměrně reálného údaje minimální úrovně dna $Z_{\min }$. Mezi jednotlivými profily však byla zaznamenána značná variabilita (obr. 5). Dokládají to údaje uvedené v tabulce 2. Průměrná odchylka minima činí $+0,16$ m, hodnota mediánu $+0,71$ m a směrodatná odchylka +0,77 m. Z toho vyplývá, že tato extrapolační metoda z hlediska průměru úroveň dna spíše nadhodnocuje. Je tedy zřejmé, že snížením sklonu

Tabulka 2. Popisné statistiky odchylek nejnižší úrovně extrapolovaného dna vưči $Z_{\min }$ při použití metody linear, double-linear a násobku n sklonů břehů přičných profilů Table 2. Descriptive statistics' overview - deviations of the lowest level in the extrapolated cross sections using the linear, double-linear estimation method [1] and multiplier $n$ method from the in situ geodetic measurements

Charakteristika Průměr Medián Min. Max. Dolníkvartil Horníkvartil $\begin{aligned} & \text { Směrodatná } \\ & \text { odchylka }\end{aligned}$

\begin{tabular}{llllllll}
\hline odchylka linear [m] & $+0,16$ & $+0,25$ & $-2,86$ & $+2,37$ & $-0,09$ & $+0,49$ & $+0,77$ \\
\hline odchylka double-linear [m] & $+0,42$ & $+0,42$ & $-2,39$ & $+2,48$ & $+0,19$ & $+0,68$ & $+0,68$ \\
\hline násobek n & 1,30 & 0,71 & $2.10-5$ & 9,48 & 0,37 & 1,40 & 1,75
\end{tabular}




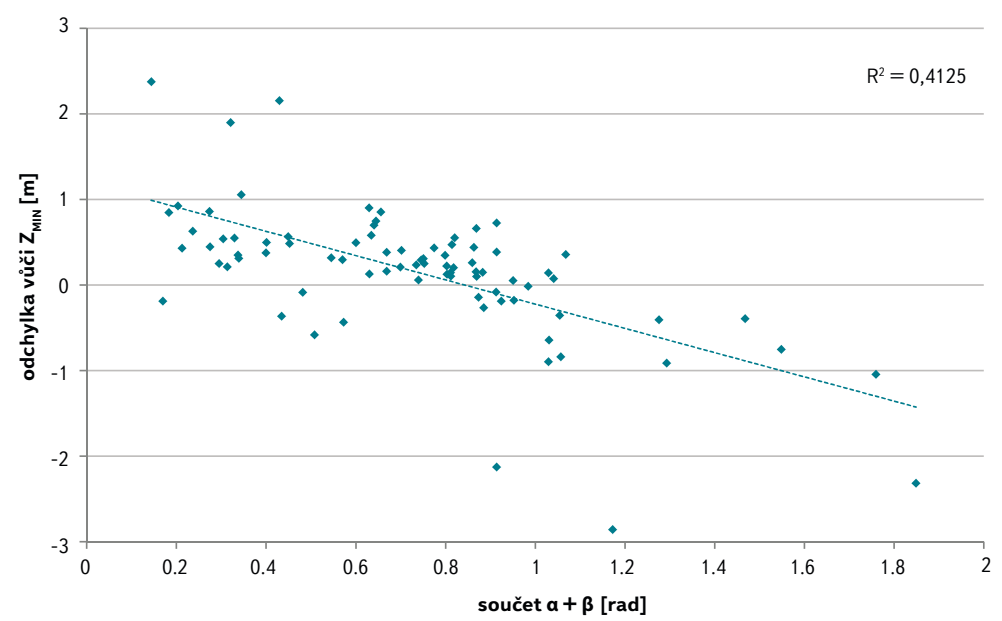

Obr. 7. Vztah odchylky nejnižší úrovně dna koryt extrapolovaných metodou linear a součtu sklonů břehů $a+\beta$ př́čných profilů

Fig. 7. Relationship of the deviations of the lowest level in the extrapolated cross sections using the linear and double-linear estimation method [1] from the in situ geodetic measurements and sums of banks' slopes for each cross section

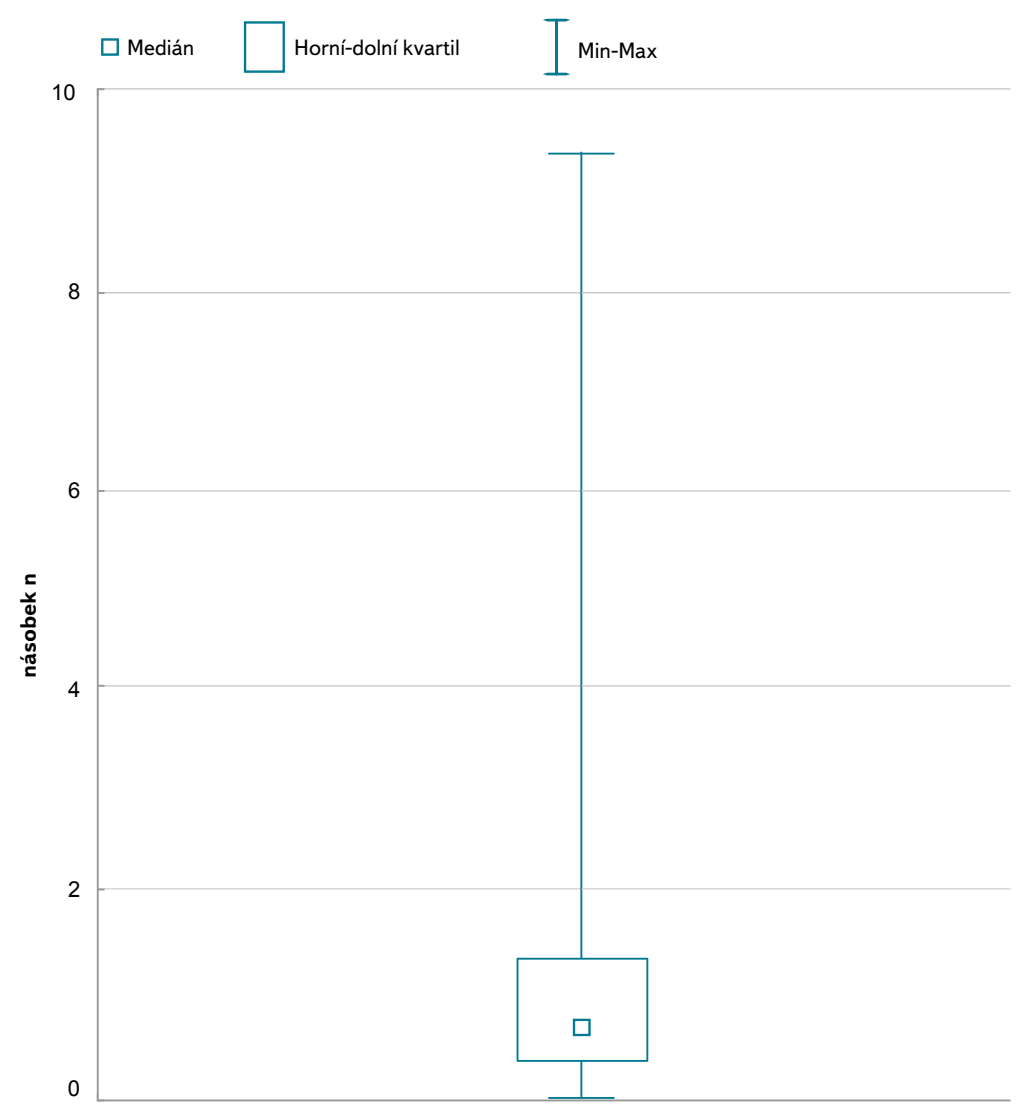

Obr. 8. Krabicový graf optimálních násobků n sklonů břehů $a, \beta$ Fig. 8. Boxplot of optimal values of multiplier $n$

břehů na polovinu původní hodnoty žádného zlepšení dosáhnout nelze. Pro úplnost jsou však i pro tuto extrapolaci hodnoty základních popisných statistik uvedeny. Pro přehlednost jsou na obr. 6 vyobrazeny krabicové grafy odchylek extrapolované minimální úrovně dna od minima zaměřeného v terénu při aplikaci obou uvedených metod.
Dále se ukázalo, že výsledná odchylka dosažené minimální úrovně příčných profilů vůči úrovni $Z_{\min }$ vykazuje určitou závislost na součtu úhlů břehů $a+\beta$. Obecně se dá tvrdit, že pro nízké hodnoty součtů sklonů břehů dochází převážně k nadhodnocení minimální úrovně dna extrapolovaného koryta a naopak (obr. 7). Hodnota korelačního koeficientu činí 0,64 (tj. střední závislost). Největší shody je dosahováno nejčastěji v rozmezí hodnot součtu $\alpha+\beta$ přibližně 0,8 až 1,0 rad (tj. přibližně $45^{\circ}$ až $57^{\circ}$ ). Nicméně, pro jednoznačnější výsledky by bylo potřebné shromáždit větší soubor příčných profilů.

Snahou bylo také nalézt optimální hodnotu násobku n úhlů a, $\beta$. Postupem bliže popsaným výše bylo zjištěno, že průměrná hodnota násobku $n$ činí pro soubor osmdesáti dvou profilů 1,30, hodnota mediánu je 0,71. Krabicový graf charakterizující rozložení hodnot $\mathrm{n}$ je uveden na obr. 8. Závislost rozložení těchto hodnot na poměru sklonů obou břehů $a, \beta$, jejich součtu ani poměru se neprokázala.

\section{ZÁVĚR}

Aplikace metody lineárních extrapolací břehů koryt z DMT vytvořeného z datové sady DMR 5 G za účelem nalezení minimální úrovně koryta ukázala, že tato metoda $v$ prevážné části prípadů vede $\mathrm{k}$ mírnému nadhodnocování minimální úrovně dna (průměrně o $+0,16 \mathrm{~m}$ ). Z toho plyne, že vhodným krokem vedoucím ke zpřesnění by bylo zvýšení sklonů břehů o jistý násobek $n$ (pro konkrétní analyzovaný soubor profilů je to průměrně 1,30). Do úvahy je však nutné brát skutečnost, že úspěšnost interpolace zde není hodnocena vzhledem k výstupům hydrodynamického modelování, ale čistě vzhledem k nejnižši úrovni koryt vodních toků. V tomto duchu je potřeba k této studii a jejím výsledkům pristupovat.

Problematickým aspektem extrapolační metody je kromě již zmíněných chyb datové sady DMR 5G (úplná střední chyba, maximální chyba) také subjektivita vymezení břehů koryt, resp. jejich počátečních a koncových bodů. Vymezení může být $v$ jednotlivých případech nejednoznačné s ohledem na proměnlivost sklonů. Další limitující skutečností je zatím poměrně omezený vzorek prričných koryt a úseků toků, pro které byla analýza provedena. K podrobnějšímu hodnocení metody by bylo žádoucí soubor přičných profilů významně rozširirit a zohlednit při tom i variabilitu koryt z hlediska jejich geometrie a z ní vyplývající nepřesnosti digitálního modelu terénu v úrovni koryta (bystřiny, zarostlá koryta, koryta s podemletými břehy, koryta se svislými břehovými zdmi, lichoběžníková koryta aj.). To by umožnilo detailně analyzovat vzájemné vztahy mezi výsledky extrapolačních metod a lépe identifikovat parametry př́rčných profilů a jejich kombinace ovlivňující úspěšnost extrapolace koryta. Díky tomu bude možné vyvinout robustní metody extrapolace koryt definovaných parametrů z podkladů, kde úplná topografie koryt vodních toků není vykreslena.

\section{Literatura}

[1] MERSEL, M.K., SMITH, L.C., ANDREADIS, K.M., and DURAND, M.T. Estimation of river depth from remotely sensed hydraulic relationships. Water Resources Research, 2013, 49, p. 3165-3179.

[2] MERWADE, V. Uncertainty in flood inundation mapping: current issues and future directions. Journal of Hydrologic Engineering, 2008, 13, p. 608-620

[3] JUNG, Y.H. and MERWADE, V. Uncertainty Quantification in Flood Inundation Mapping Using Generalized Likelihood Uncertainty Estimate and Sensitivity Analysis Journal of Hydrologic Engineering, 2012, 17, p. 507-520

[4] DOTTORI, F., DI BALDASSARRE, G., and TODINI, E. Detailed data is welcome, but with a pinch of salt: Accuracy, precision, and uncertainty in flood inundation modeling. Water Resources Research 2013, 49, p. 6079-6085.

[5] BROCCA, L., MELONE, F., MORAMAREO, T. A continuous rainfall-runoff model as a tool for the critical hydrological scenario assessment in natural channels In: TANIGUCHI, M., BURNETT, W.C., FUKUSHIMA, Y UMEZAWA Y (Eds). International Conference on Hydrological Changes and Management from Headwaters to the Ocean. Kyoto, Japan: CRC PRESS-TAYLOR \& FRANCIS GROUP, 2009, p. 175-179. 
[6] PARODI, U. and FERRARIS, L. Influence of stage discharge relationship on the annual maximum discharge statistics. Natural Hazards, 2004, 31, p. 603-611.

\section{[7] BRACHTL, I. a TAUS, K. Súčinitele drsnosti otvorených kanálov. Bratislava: VÚV, 1962, 42 s.}

[8] PAPPENBERGER, F., BEVEN, K., HORRITT, M., and BLAŽKOVÁ, Š. Uncertainty in the calibration of effective roughness parameters in HEC-RAS using inundation and downstream level observations. Journal of Hydrology, 2005, 302, p. 46-69.

[9] SMELÍK, L. Návrh metodiky stanovení součinitele drsnosti otevřených koryt. Dizertační práce. Brno: Vysoké učení technické v Brně, 2015, 131 s.

[10] LAGACHERIE, P., MOUSSA, R., MORMARY, D., and MOLENAT, J. Effects of DEM data source and sampling pattern on topographical parameters and on a topography-based hydrological model. In: KOVAR, K., NACHTNEBEL, H. P. (Eds.). Application of Geographic Information Systems in Hydrology and Water Sources Management. Vienna: IAHS, 1996, 235, p. 191-199.

[11] HARDY, R.J., BATES, P.D., and ANDERSON M.G. The importance of spatial resolution in hydraulic models for floodplain environments. Journal of Hydrology, 1999, 216, p. 124-136.

[12] HORRITT, M.S. A methodology for the validation of uncertain flood inundation models. Journa of Hydrology, 2006, 326, p. 153-165.

[13] RABER, G.T., JENSEN, J.R., HODGSON, M.E., TULLIS, J.A., DAVIS, B.A., and BERGLUND, J. Impact of LiDAR nominal post-spacing on DEM accuracy and flood zone delineation. Photogrammetric Engineering \& Remote Sensing, 2007, 73, p. 793-804.

[14] JUNG, Y. and MERWADE, V. Estimation of uncertainty propagation in flood inundation mapping using 1-D hydraulic model. Hydrological Processes, 2015, 29, p. 624-640.

[15] MANFREDA, S., NARDI., F., SAMELA, C., GRIMALDI, S., TARAMASSO, A. C., ROTH, G., and SOLE, A. Investigation on the use of geomorphic approaches for the delineation of flood prone areas. Journal of Hydrology, 2014, 517, p. 863-876

[16] ALRAJHI, M., KHAN, M., KHAN, M.A., and ALOBEID, A. Influence of DEM in Watershed Management as Flood Zonation Mapping. The International Archives of the Photogrammetry, Remote Sensing and Spatial Information Sciences, 2016, 41

[17] BATES, P.D. Remote sensing and flood inundation modeling. Hydrological Processes, 2004, 18, p. 2593-2597.

[18] QUADROS, N.D., COLLIER, P.A., and FRASER, C.S. Integration of bathymetric and topographic LiDAR: a preliminary investigation. The International Archives of the Photogrammetry, Remote Sensing and Spatial Information Sciences, 2008, 36, p. 1299-1304.

[19] SMEECKAERT, J., MALLET, C., and DAVID, N. Large-scale classification of water areas using airborne topographic lidar data. Remote Sensing of Environment, 2013, 138, p. 134-148.

[20] TSUBAKI, R. and KAWAHARA, Y. The uncertainty of local flow parameters during inundation flow over topographies with elevation errors. Journal of Hydrology, 2013, 486, p. 71-87.

[21] DAL CIN, C., MOENS, L., DIERICKS, P., BASTIN, G., and ZECH, Y. An integrated approach for realtime floodmap forecasting on the Belgian Meuse river. Natural Hazards, 2005, 36, p. 237-256.

[22] WESTAWAY, R.M., LANE, S.N., HICKS, D.M. Remote sensing of clear-water, shallow, gravel-bed rivers using digital photogrammetry. Photogrammetric Engineering and Remote Sensing, 2001, 67, p. 1271-1281.

[23] SANDERS, B.F. Evaluation of on-line DEMs for flood inundation modeling. Advances on Water Resources, 2007, 30, p. 1831-1843.

[24] HILLDALE, R.C. and RAFF, D. Assessing the ability of airborne LiDAR to map river bathymetry. Earth Surface Processes and Landforms, 2008, 33, p. 773-782

[25] PODHORANYI, M. and FEDORCAK, D. Inaccuracy introduced by LiDAR-generated cross sections and its impact on 1D hydrodynamic simulations. Environmental Earth Sciences, 2015, 73, p. 1-11.

[26] NAKI DF12P01OVV035 Identifikace významných území s kulturně historickými hodnotami ohroženými prírodními a antropogenními vlivy (2012-2015, Ministerstvo Kultury ČR).

[27] ZÚ \& VGHÚ. Technická zpráva k digitálnímu modelu reliéfu 5. generace (DMR 5G), 2016

\section{Autor}

Mgr. Martin Caletka ${ }^{1,2}$

凶martin.caletka@vuv.cz

'Výzkumný ústav vodohospodářský T. G. Masaryka, v. v. i., pobočka Brno ${ }^{2}$ Geografický ústav, Př́rodovědecká fakulta, Masarykova univerzita v Brně

Příspěvek prošel lektorským řízením.

\section{POSSIBILITIES OF EXTRAPOLATION OF DIGITAL TERRAIN MODEL RASTER DMR 5G}

\section{CALETKA, M. $^{1,2}$}

'TGM Water Research Institute, p. r. i., Brno Branch

${ }^{2}$ Department of Geography, Faculty of Science, Masaryk University

Keywords: Digital Model of Relief $5^{\text {th }}$ Generation - DMR 5G digital model of terrain - extrapolation - GIS - channel geometry

Airborne laser imaging (LiDAR) has been carried out throughout the Czech Republic, enabling the creation of raster of digital model of terrain. This material is widely used in various fields. From the point of view of hydrology demands, however, the shortcoming of this technology resides in the absence of accurate/complete channel topography due to the absorption of the near-infrared laser beams by water. Therefore, it is necessary to correct the data by replacing parts the original raster by more accurate data, such as geodetic or sonar measurements. However, there are some procedures that allow extrapolation of the geometry directly from the original rasters, based on the bank slopes within cross sections. In this work, linear and double-linear procedure applied by Mersel et al. [1] is used.

The presented paper is an introductory step towards the use of similar extrapolation procedures. In total, 82 cross sections were measured by theodolite. Subsequently, raster DMR 5 G (Digital Model of Relief $5^{\text {th }}$ Generation) was used for the extraction of 82 corresponding cross sections, on which the extrapolation was performed. The analysis revealed that the linear estimation method by Mersel et al. [1] results in slight overestimation of the minimum level of the bottom over the actual measured values (measured in situ). However, it should be noted that the analysis has so far been performed purely on the basis of comparison with the minimal level within cross sections, not taking into account the impact on the results of hydrodynamic modelling, for instance. 